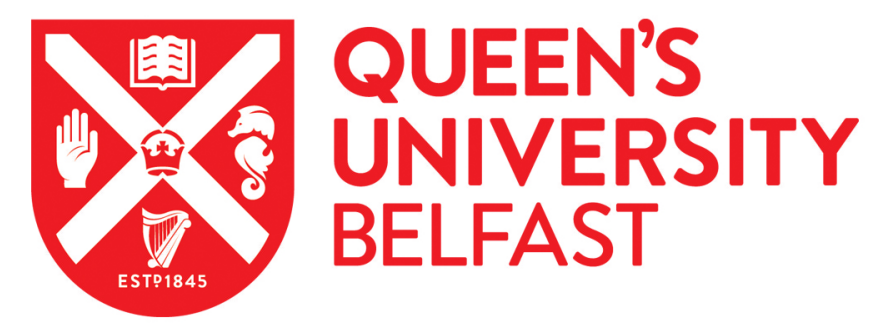

\title{
Bleeding time, stroke and myocardial infarction: the Caerphilly prospective study
}

Elwood, P. C., Pickering, J., Yarnell, J., O'Brien, J. R., Shlomo, Y. B., \& Bath, P. (2003). Bleeding time, stroke and myocardial infarction: the Caerphilly prospective study. Platelets, 14(3), 139-141.

\section{Published in:}

Platelets

Queen's University Belfast - Research Portal:

Link to publication record in Queen's University Belfast Research Portal

\section{General rights}

Copyright for the publications made accessible via the Queen's University Belfast Research Portal is retained by the author(s) and / or other copyright owners and it is a condition of accessing these publications that users recognise and abide by the legal requirements associated with these rights.

Take down policy

The Research Portal is Queen's institutional repository that provides access to Queen's research output. Every effort has been made to ensure that content in the Research Portal does not infringe any person's rights, or applicable UK laws. If you discover content in the Research Portal that you believe breaches copyright or violates any law, please contact openaccess@qub.ac.uk. 


\title{
Bleeding time, stroke and myocardial infarction: the Caerphilly prospective study
}

\author{
P.C. Elwood, Janet Pickering, J. Yarnell, J.R. O'Brien*, Y. Ben Shlomo, P. Bath
}

The stressed bleeding time is a simple 'global' test of haemostasis, dependent upon platelet function, rheology, thrombosis and intimal function. It could be of considerable value in clinical practice if it were shown to be predictive of vascular discase events. A stressed bleeding time test was done on 1319 men aged $55-69$ years in the Caerphilly Cohort Study of Heart Disease, Stroke and Cognitive Decline. The men were followed-up and during the following 7-10 years 155 men had a myocardial infarction (MI) and 72 an ischaemic stroke. The mean bleeding time was 323 (SD 113) s. This was shorter in men who smoked by an average of $45 \mathrm{~s}$, and lengthened in men who took aspirin daily by $40 \mathrm{~s}$. After making statistical adjustments for numerous possible confounding factors, the relative odds (ROs) of an MI within the third of men with the longest bleeding times, compared to the third with the shortest times, was $0.90(0.40-2.03)$. For ischaemic stroke, the ROs in the third of men with the longest times were $1.42(0.39-5.21)$. The stressed bleeding time does not predict either MI or ischaemic stroke. It has no place in health screening.

\section{Introduction}

Since it was first described in 1901 there has been sustained interest in the bleeding time test. One review ${ }^{1}$ lists over 800 references, and another, over $200 .^{2}$ The test is of interest as it is dependent upon a host of factors involved in haemostasis, including endothelial function, platelet aggregation, rheology and other haemostatic fuctors. It is of established value in the detection of von Willebrand's disease and in the prediction of excessive bleeding in surgical procedures. ${ }^{3}$ Aspirin and other anti-platelet agents prolong the bleeding time and a leading article in the Lancet stated that the test "has a place in epidemiological field work". 3

P.C. Flwood, Janet Pickering, University of Wales College of Medicine, Wales, UK; J. Yarnell, Queen's University Belfast, Belfast, N. Ireland; $Y$. Ben Shlomo, Department of Social Medicine, University of Bristol, Bristol, UK; J. R. O'Brien, St Mary's Hospital, Portsmouth, UK; P. Bath, University of Nottingham, Nottingham, UK.

Correspondence to: Professor Peter Elwood, Llandough Hospital, Penarth CF64 2XW, UK. E-mail: pelwood@doctors. org.uk

* John O'Brien died October 2002.
Bleeding time has been shown to be reduced in patients with vascular disease and its possible value in the prediction of cardiovascular disease has been repeatedly suggested. ${ }^{3-7}$ It is a simple test, requiring no elaborate apparatus, and it could have a valuable place in clinical practice, and in particular, in relation to decisions about aspirin prophylaxis, if it were shown to be predictive of future myocardial infarction (MI) and/or stroke. However, there appears to have been no report of its predictive power for vascular disease.

A wide range of haemostatic tests were performed in the Caerphilly Cohort Study of Heart Disease, Stroke and Cognitive Decline, including platelet aggregation $^{8}$ and a bleeding time test. ${ }^{9}$ In this report we give results for the predictive power of the test for incident MI or ischaemic stroke.

\section{Methods}

The Caerphilly Study ${ }^{10}$ was set up in 1979-83 on a population sample of 2512 men aged $45-59$ years. In the third phase of the study, when the men were 5569 years, blood was taken after an overnight fast, 
Table 1. ROs of a vascular event in thirds of men defined by the levels of the test

\begin{tabular}{|c|c|c|c|c|c|c|c|}
\hline & \multirow{2}{*}{$\begin{array}{l}\text { Number } \\
\text { of men }\end{array}$} & \multicolumn{3}{|c|}{ Incident Ml } & \multicolumn{3}{|c|}{ Incident stroke } \\
\hline & & No. & $\mathrm{RO}^{1}$ & $\mathrm{RO}^{2}$ & No. & $\mathrm{RO}^{1}$ & $\mathrm{RO}^{2}$ \\
\hline $\begin{array}{l}\text { Bleeding time } \\
\text { shortest } 1 / 3 \\
\text { middle } 1 / 3 \\
\text { Longest } 1 / 3 \\
\text { Significance of trend }\end{array}$ & $\begin{array}{l}455 \\
427 \\
437\end{array}$ & $\begin{array}{l}52 \\
49 \\
54\end{array}$ & $\begin{array}{c}1.00 \\
1.04 \\
1.12 \\
P=0.92\end{array}$ & $\begin{array}{l}1.00 \\
1.26(0.60-2.63) \\
0.90(0.40-2.03) \\
\quad P=0.62\end{array}$ & $\begin{array}{l}20 \\
26 \\
26\end{array}$ & $\begin{array}{c}1.00 \\
1.91 \\
1.80 \\
P=0.23\end{array}$ & $\begin{array}{l}1.00 \\
2.01(0.58-6.92) \\
1.42(0.39-5.21) \\
\quad P=0.63\end{array}$ \\
\hline
\end{tabular}

1 Differences (1) have been adjusted for age, social class, smoking, aspirin and prevalent heart disease.

${ }^{2}$ Differences (2) have been adjusted for the above, plus fasting cholesterol and triglycerides, platelet count, volume and aggregation, haematocrit, fibrinogen, viscosity, von Willebrand factor, Factor 7 and white cell count.

${ }^{3}$ Bleeding times have been adjusted throughout for differences between observers.

between 06.00 and $09.30 \mathrm{~h}$ and immediately following venesection the stressed bleeding time was estimated. ${ }^{9}$ A sphygmomanometer cuff was inflated to $40 \mathrm{mmHg}$ on the arm which had not been used for venesection. After $30 \mathrm{~s}$, a double cut was made transversely on the anterior surface of the mid forearm with a Simplex II device (Organon Tekina Corporation). Blood was blotted from the edge of each cut at 30-s intervals using a piece of standard filter paper. The duration of bleeding from each cut was separately recorded and the mean of the two times used in subsequent analyses. Three observers were involved in the clinics and the order in which men were seen was haphazard.

At intervals, details of all possible vascular events were collected from the men and from GPs and hospital records, and standard criteria applied to identify myocardial infarction (MI) and stroke. ${ }^{11,12}$

\section{Results}

Bleeding times were available for $1319 \mathrm{men}$, and during the 7-10 years after the tests 155 men had an MI and 72 had a stroke.

Three doctors did the tests and their mean times, in seconds, were: $282 \mathrm{~s}$ (SD 128); $331 \mathrm{~s} \mathrm{(SD} \mathrm{99);} \mathrm{and}$ $351 \mathrm{~s}$ (SD 98). These means differ significantly but the variances are homogeneous and the overall mean is $323 \mathrm{~s}$ (SD 113). The reproducibility of estimate, judged from coefficients of variation, was $11.9 \%$ based on the double cut made at the same time and $15.4 \%$ based on two tests at 2-week intervals, performed on 41 men.

A wide range of possible determinants of bleeding time were examined. By far the most important are smoking, which shortened the time by $45 \mathrm{~s}$, and daily aspirin which lengthened it by $40 \mathrm{~s}$.

The overall mean bleeding time in men who remained free of a vascular event, corrected for observer, was $322 \mathrm{~s}$ (SD 116). After adjusting for possible confounding by the factors listed below the table, the bleeding time in men who experienced an MI was $3 \mathrm{~s}$ shorter $(95 \% \mathrm{CI}-27$ to +22$)$, and in those who experienced a stroke it was $14 \mathrm{~s}$ longer $(-25$ to +54$)$.
Table 1 displays the results with the men divided into thirds by the bleeding time. For neither MI nor ischaemic stroke is there evidence of significant prediction.

\section{Discussion}

The stressed bleeding time, although crude, is a very simple test giving an integrated measure of many mechanisms involved in haemostasis. The similarity between the 'within subject' and the 'between times' variation suggests that it is fairly stable within a subject, most of the variability coming from the test itself, probably from the judgement as to when bleeding has ceased.

The strengths of our study include the facts that it was based upon a large representative sample of older men; the disease events are all incident and the number of events is sufficient to allow a meaningful examination of $\mathrm{MI}$ and stroke separately.

Judging from the number of papers in the literature, there has been sustained interest in the test over many years. Many of the studies reported have, however, been based upon small numbers of selected patients, or unrepresentative control subjects, or on patients with a recent infarct.

The present report appears to be the first prospective study of a bleeding time test in a representative population sample of subjects. The results are unexpected in that there is no prediction of MI, and the prediction of ischaemic stroke, although non-significant, suggests that it is the men with the shortest bleeding times who have the lowest risk. In both these findings the data are consistent with the results of equally unexpected results of platelet aggregation tests in the same cohort. ${ }^{8}$ The results therefore give no encouragement for the use of bleeding time lests in the evaluation of vascular disease.

\section{Acknowledgements}

The Caerphilly study was conducted by the former MRC Epidemiology Unit (South Wales) and was funded by the Medical Research Council of the 
United Kingdom. The archive is now maintained by the Department of Social Medicine in the University of Bristol. Janet Pickering was supported by The British Heart Foundation. Philip Bath is Stroke Association Professor of Stroke Medicine.

\section{References}

1. Rogers RP. Bleeding time tables: a tabular summary of pertinent literature. Semin Thromb Haemost 1990; 16: 21-144.

2. Rogers RP, Levin J. A critical reappraisal of the bleeding time. Semin Thromb FIaemost 1990; 16: 1-20.

3. Anon. The bleeding time. Lancet 1991; 337: 1447-8.

4. O'Brien JR, Jamieson $S$, Etherington $M$, et al. Stressed template bleeding-time and other platelet-function tests in myocardial infarction. Lancet $1973 ; 1 ; 694-6$.

5. O'Brien JR, Etherington MD, Jamieson $\mathrm{S}$, et al. Blood changes in atherosclerosis and long after myocardial infurction and venous thrombosis. Thromb Diath Huemorrh 1975; 34: 483-97.
6. Daniel S, O'Brien JR, John JA. Platelets in the prediction of thrombotic risk. Atherosclerosis 1982; 45: $91-9$.

7. Milner PC, Martin JF. Shortened bleeding time in acute myocardial infarction and its relation to platelet mass. $\mathrm{Br} \mathrm{Med}$ $J$ (Clin Res Ed) 1985; 290: 1767-70.

8. Hiwood PC, Beswick A, Pickering J, el al. Platelet tests in the prediction of myocardial infarction and stroke: evidence from the Caerphilly study. 2001; 113: 514-20.

9. Elwood PC, Beswick AD, O'Brien JR, Yarnell JWG, Layzell JC, Limb ES. Inter-relationships between haemostatic tests and the effects of some dietary determinants in the Caerphilly cohort older men. Blood Coagul Fibrinolysis 1993; 4: 529-36.

10. Caerphilly and Speedwell Collaborative Group. The Caerphilly and Speedwell collaborative heart disedse sludies. I Epidemiol Community Health 1984; 38: 259-.62.

11. Rose GA. The diagnosis of ischemic heart pain and intermittent claudication in fieid studies. Bull WHO 1962; 27: $645 \cdot 58$.

12. Greenwood R, McCarron $P$, Elwood $P$, et al. The incidence and aetiology of stroke in the Caerphilly and Speedwell Collaborative Studies I:methods and incidence of events. Public Health 2001; 115: 4-11. 
